\title{
The Seven Plant Species - A Basis of Nutrition of Ancient Israel
}

\author{
Zofia Włodarczyk* \\ Department of Ornamental Plants, University of Agriculture in Krakow, Poland \\ *Corresponding author: Zofia Włodarczyk, Department of Ornamental Plants, University of Agriculture in Krakow 29 \\ Listopada 54, 31-425 Kraków, Poland
}

\begin{tabular}{|c|}
\hline ARTICLE INFO \\
\hline Received: 杫 February 08, 2020 \\
\hline Published: 幽 February 18, 2020 \\
\hline
\end{tabular}

Citation: Zofia Włodarczyk. The Seven Plant Species - A Basis of Nutrition of Ancient Israel. Biomed J Sci \& Tech Res 25(4)-2020. BJSTR. MS.ID.004239.

\begin{abstract}
The seven plant species mentioned in the Bible describes the fertility of the Promised Land. These are: wheat, barley, the grapevine, the fig tree, the pomegranate tree, the olive tree and the date palm. They represent some of the earliest domesticated plants in the Middle East. They could serve as basic food all year round, because their fruits were easy to store. Olive oil, wine and fig fruit were also used for medicinal purposes. Contemporary knowledge confirms the exceptional nutritional value of these seven species, as well as their health-related benefits.
\end{abstract}

Keyword: Seven Species; Bible; Ancient Diet; Fundamental Nutrients

\section{Introduction}

The natural conditions of the Fertile Crescent, an area that stretches from Egypt, through the Zagros Mountains, to Mesopotamia, were conducive to the domestication of plants and animals $[1,2]$. The Neolithic Revolution led to changes in the manner of procuring foodstuffs. People started to produce food by cultivating plants, which allowed them to adopt a settled lifestyle and the development of human societies. In the Bible, there are various references to the economic life of the ancient peoples of the Middle East, their diets and religious rituals (Exodus 23:14-16, Deuteronomy 16:9-10, Deuteronomy 16:13-14). These references mention numerous plants and the manner in which they were used. However, the seven plant species that provided the most fundamental nutrients and were of medical use [3] were given particular significance. They include two species of grains (wheat and barley), the grapevine, the fig tree, the pomegranate tree, the olive tree and the date palm, which bore dates used to produce honey [4]. The vital importance of these seven plant species to this territory is attested in the biblical description of the Promised Land that had been prepared for the Israelites: "For the LORD your God is bringing you into a good land, a land of brooks of water, of fountains and springs, flowing out in the valleys and hills, a land of wheat and barley, of vines and fig trees and pomegranates, a land of olive trees and honey, a land in which you will eat bread without scarcity, in which you will lack nothing, a land whose stones are iron, and out of whose hills you can dig copper" (Deuteronomy 8:79). The presence of the seven species is an indispensable element of the biblical gardens, founded worldwide since 1940 as a way of popularizing biblical content by displaying plants mentioned in the Bible $[5,6]$.

\section{Wheat}

The oldest trace of wild wheat grains, estimated to be 23 thousand years old, was discovered on the shores of the Sea of Galilee, at the Ohalo II site [7]. Wild emmer wheat (Triticum dicoccoides) was gathered from where it grew in the wild as due to its brittle rachis ripe grains were spontaneously scattered round [8]. The introduction of conscious wheat cultivation is attributed to the Natufian tribes, which lived in the Upper Paleolithic period (10000-8000 BC) [2]. The process of the domestication of grain was based on the human artificial selection of genetic mutants which possessed a non-brittle rachis. In this case, the mature ear of grain stayed intact until threshing $[1,8]$, so it could be harvested by humans in a controlled way.

Emmer wheat (Triticum diccocum), one of the first domesticated species of wheat, has non-brittle rachises, but as a hulled form possesses glumes tightly adherent to the grain, which are not removed by threshing [9]. It was undoubtedly cultivated in biblical times in Israel [10-13] and Egypt [14] and is dated to at least 7000 
BC. This has been confirmed by archaeological digs, with the oldest one located near Petra, where seeds of emmer wheat were found in the clay of a burned-down house, and in Jericho, dated to a period around 2500 BC [12]. Emmer wheat flour was coarse, as both the grain and glumes could be grounded. The cultivation of emmer wheat began to lose its significance during the Bronze Age (from around $5000 \mathrm{BC}$ ) [15] and was gradually replaced by free-threshing forms: durum wheat (Triticum durum) and bread wheat (Triticum aestivum). Their so-called naked grains can be released from the chaff during threshing [9], yielding pure grains, which results in better quality flour. Zohary argues that the main species of wheat to be cultivated during biblical times was durum wheat [11]. Hepper agrees that the durum wheat species was cultivated in biblical times in Palestine, along with bread wheat. It is also believed that the latter species of wheat was the most significant one during the later period, after Sennacherib's conquest of Lachish in 701 BC [12]. $90 \%$ of grain samples from this period that were found in Lachish belonged to the species Triticum aestivum.

\section{Barley}

The cultivation of barley began in south-east Asia around 9000 BC. This is evidenced by the discovery of this grain in Netiv Hagdud in Israel, a Neolithic settlement from around 9970-9400 BC [9]. Due to its higher resistance to draught when compared to wheat, it was even found on the edges of deserts [11]. Two species of barley were cultivated: Hordeum distichum and Hordeum hexastichum. Like emmer wheat, barley possesses hulled grains [9]. During biblical times, both wheat and barley flour were used. Wheat flour was considered a luxury (Judges 7:13; 2 Kings 4:24), while barley flour was consumed by poor people (John 6:9). Milled broad beans and lentils were often added to grain flour (Ezekiel 4:12; Hosea 7:8). Barley was also used to produce beer [16]. Cereal grains could also be eaten raw or roasted (Ruth 2:14; Leviticus 2:14; 1 Samuel 17:17; 2 Samuel 17:28). Grain roasting was performed on a hot stove and on a flat piece of iron [12] or on a convex sheet of tin [7]. Such grain was kept for a long time and used as provision during travelling (1 Samuel 25:18). Roasting caused the chaff to separate from the grain, which was essential in the case of hulled cereal grains of emmer wheat and both species of barley, to produce whiter and softer flour. Wheat grains were also cooked with honey, pomegranate seeds or almonds [7].

Cereal grains were primarily cultivated to obtain flour, which was further used for bread baking and cooking various meals. As stone milling was used, the flour usually included high amounts of grit, resulting in dental abrasion. Preserved example of bread found in an Egyptian tomb even glittered due to the numerous grit content [12]. Bread dough was kneaded in a special shallow trough made of wood or pottery [12]. Two types of bread were baked in ancient Israel: unleavened bread (macca) and sourdough bread (Mark 6:41; Luke 9:16). One required a leavening agent to prepare the latter $[12,17]$. Bread loaves were round and not too thick, often having a hole in the middle so that they could be threaded on a stick, which was called the staff of the bread (Ezekiel 14:13). The form of the bread was adapted to the manner of eating it, i.e. small pieces of it were torn off and dipped in sauce or put into other types of food [7].

\section{Vine}

Botanists place the first instances of grapevine cultivation (Vitis vinifera) in the mountainous regions of Armenia and in territories bordering on the Caspian Sea $[10,12,18]$. The grapevine was cultivated by the Nabateans [19]. In the Holy Land, the oldest remains of vine cultivation in Jericho are dated to 3000 years BC. In Egypt, grapevine plantations were present even earlier, as attested by seals with the image of a grape bunch dated to the period of the First Dynasty (c. 2960-2770 BC) [20,21]. The discovery of numerous winepresses and jars with labels in the area of biblical Gibeon and Gezer indicates that these places were wine-making centres [18]. The Talmud mentions around 60 varieties of wine [22]. In biblical times, red wine was more popular than white wine [22]. Wine was used as medicine, as a wound disinfectant (Luke 10:34; Timothy 5:23) [12,23]. It was drunk during holidays (Nehemiah 8:10) and wedding parties (John 2:3). Adding wine to water that was to be stored for a longer time protected it from the development of harmful microorganisms. It was also recommended to drink diluted wine (2 Maccabees 15:39) because of its curative properties (1 Timothy 5:23). Grape wine could also be turned into wine vinegar used as a refreshing drink or as bread dip (Ruth 2:14).

Dried grapes - raisins - were a high-calorie product eaten at all times of the year, and were excellent food for travellers and desert dwellers [19] (1 Samuel 25:18; 1 Samuel 30:12; 1 Chronicles 12:41). Prior to being sundried, fruit of the vine was placed in boiling water which contained a mixture of wood ash and olive oil [18]. Raisins were eaten directly (1 Samuel 30:12) or as compressed cakes of raisins (Isaiah 16:7). Raisin cakes were very popular (2 Samuel 6:19; Song of Songs 2:5; Hosea 3:1), and some places, like Kirhareseth, were even famous for their production (Isaiah 16:7) [18].

\section{Fig}

The oldest traces of common figs (Ficus carica) were discovered in Jericho and are dated to the Neolithic period (around 7000 BC), and in Gezer, dated to around 5000 BC $[12,14,18]$. It is presumed that the figs were cultivated around the Mediterranean and Caspian basins already in the Bronze Age or perhaps even earlier [24]. Iron-Age fig cultivation was confirmed by discoveries made in Beit Shemesh, where fig seeds were found in addition to pressed fig fruit mixed with lentils and placed in jars [18]. Fig trees are also shown on bas-reliefs found in Nineveh (currently on display at the the British Museum), depicting the siege of Lachish by Sennacherib in 701 BC (2 Kings 18:13), which further attests to their cultivation during the Iron Age $[2,20]$. Sources also mention figs as fruit that were imported into Egypt, along with olives, nuts and honey, around the period c. 2700 BC [18]. 
The first early fig fruit crop, harvested in June, was consumed raw and believed to be a delicacy (Hosea 9:10; Micah 7:1; Nahum 3:12; Jeremiah 24:2). The fruit from the second harvest, which ripened between August and September (Isaiah 16:9; Jeremiah 48:32) were stored for the winter or kept as travel supplies (2 Samuel 16:1-2). Dried figs were stored either loose, threaded on string [18], or were mashed into cakes (1 Samuel 30:12; 2 Kings 20:7). Dried fig cakes were rich in sugar [12]. Fig fruits were added to wine to make it aromatic [22]. Dioscorides wrote that juice from fig leaves or sprouts was added to milk for coagulation [25]. A freshly cut fig tree shoot, from which milk juice leaked, was used to mix milk during cheese production [26]. Fig fruits were also used in medicine. Ancient Egyptians prepared a drink consisting of figs, milk and beer to alleviate stomach disorders $[14,26]$ and an extract of figs, acacia leaves, honey and ochre for heart and lung diseases. Coptic medicine remedies based on fig fruit were used to treat skin conditions. One such case is also mentioned in the Book of Isaiah (38:21) and the Second Book of Kings (20:7), in which Hezekiah is treated by applying a cake of figs to the boil.

\section{Pomegranate}

The pomegranate tree (Punica granatum) originates in the southern region of the Caspian Sea, but it started to be cultivated in the area of the Mediterranean [10,12,27]. Pomegranates cultivation in Canaan was proved during excavation of Jericho, where a wooden bowl in the shape of a pomegranate fruit and real pomegranates $\mathrm{c}$. 1650 BC were found $[12,14,20]$. Dated to the Bronze Age remains of these fruits were found in Gezer as well as whole dried fruits in caves near En-Gedi $[12,20]$. Israelites had to become familiar with pomegranate cultivation during their stay in Egypt, as they complained about the lack of grain, figs, grapes and pomegranates while wandering in the desert (Numbers 20:5). There are sources which attest that pomegranate cultivation in Egypt started during the eighteenth dynasty (1550 BC) and was derived from Palestine $[12,14,20]$. Wall sculptures and numerous remains of this plant found in Egyptian tombs are dated to that and later periods [14].

In antiquity, pomegranates were cultivated for their juicy flesh. Their hard shell enabled the easy storage and transport of fruits during travelling. Pomegranate juice effectively quenched thirst and was also used to produce wine through fermentation (Song of Songs 8:2) [12,18,20]. Fresh, soft pomegranate seeds, either soaked in honey or dried, were consumed as sweets $[11,28]$. The bark and roots, as well as fruit rind, were used to produce ink [11]. The rind of unripe pomegranate fruit, as well as its flowers, contain red pigment, which was used to dye leather [22,28]. A extract from pomegranate fruit was used as a remedy for diarrhoea and dysentery [29], stomach ailments and parasites [30]. The curative properties of pomegranate tree bark, which was used to treat tapeworm infections, had already been used in Egypt already since the time of the pharaohs, as attested in medical papyruses from the period of the early New Kingdom period [14]. Quintus Gargilius
Martialis, a third-century Roman writer, in De pomis seu Medicina ex pomis reports that dry ground bark, which was used to produce an extract used for dental treatments and swollen gums, while flowers ground with honey were used to treat wounds [30]. Pomegranate juice is still used in folk medicine as a remedy for heart-related ailments [12].

\section{Olive Trees}

The oldest remains of olive plants (Olea europaea) were found in ancient Palestine, around Chalcolithic settlements (4300-3500 BC) in Tulalat al-Ghassul, on the northern edge of the Dead Sea, in Nahal Mishmar (from 3500-3300 BC) and in Arad (Bronze Age) $[2,12,20]$. Olive stones were found in Lachish, an ancient Canaanite city (present-day Tell ed-Duweir) $[11,12]$ and were dated to the period of the end of the early Bronze Age and the start of its middle period (third/second millennium BC). Olive stones, grain seeds, date stones and legume plant seeds from the period between 3700-3500 BC were excavated in caves near the Dead Sea [11,12]. The fresh olives were usually consumed salted, pickled in vinegar cooked or dried. The bitterness was reduced by submerging in a hot alkaline solution and then salted [12,20]. However, olives were primarily used to produce olive oil. Olives, contrary to grapes, are hard and have sharp stones, thus oil pressing had to be performed in two stages. First, the fruit were crushed using a stone wheel, and then subjected to constant pressure over a long period of time in an olive press [18]. In Palestine, olive oil was produced and exported to Egypt, as attested c. $1800 \mathrm{BC}$ in the anonymous chronicle entitled "The Tale of Sinuhe" [14,20].

The kings David and Solomon developed olive cultivation, and the latter exported olives to Egypt (Hosea 12:2) and exchanged them with Hiram, the king of Tyre, for timber and construction services (tenth century BC) (1 Kings 5:24: 2 Chronicles 2:14-15). Olive oil was a basic component of diet for both the rich and the poor (Isaiah 1:6; Ezekiel 16:13; Ezekiel 16:19; 1 Kings 17:23; 2 Kings 4:2). The poor widow from Sarepta had "only a handful of flour in a jar and a little olive oil in a jug" (1 Kings 17:12). Aromatic balms and ointments were made by boiling medicinal plants in olive oil, while aromatic oils were obtained by soaking flowers in olive oil $[12,20]$. Two jars of a balm made from linden flowers and olive oil were found in an Egyptian tomb from around 1400 BC [26]. Medicinal use of olive oil in the wounds washing is attested by Bible quotes (Isaiah 1:6; Luke 10:34), and the supernatural aspect, i.e. the possibility of healing in response to prayers by the faithful, is mentioned in the Epistle of James (James 5:14-15). Olive oil was also used in rituals of cleansing from defiling skin diseases (Leviticus 14:15-18) [20].

\section{Date Palm}

The date palm (Phoenix dactylifera) belongs to some of the longest cultivated arborescent plants. The earliest cultivation of these plants in Mesopotamia began in the Middle East about 
4000 years BC [18]. The high level of knowledge concerning the cultivation of this plant is evidenced by findings of archaeological digs, in particular, that of an Assyrian bas-relief from around 3000 $\mathrm{BC}$, depicting artificial cross-pollination of the date palm $[10,12,28]$. Hebrews were familiar with this plant and valued it greatly, primarily as a food source. In his writings, Aristeas, an officer of Ptolemy II Philadelphus (277-270 BC), reported that the Israelites loved to cultivate the land, which abounded among others in olive trees, grain, vineyards and countless date palms [20]. Like fig trees, date palm trees are also shown on bas-reliefs found in Nineveh depicting the siege of Lachish by Sennacherib in 701 BC [20].

Being high-energy fruits [12,31,32], dates were consumed fresh, dried or in a form of pressed cakes. Several types of drinks were made from the date palm. Date honey, a very sweet syrup similar to honey, was obtained from pressed ripe dates $[4,12,20]$. It is known as dibs in Arabic [12]. In Egypt, honey produced from dates was used to produce beer [14]. Another type of syrup was obtained by piercing the spathe surrounding the young date inflorescence releasing the juice [28], which subjected to fermentation, resulted in a strong alcoholic drink, known as sycera in Hebrew (Micah 2:11, Leviticus 10:9, Lukas 1:15) [13,28]. This drink was distinct from wine produced from ripe date fruits [33]. Date stones, either ground, soaked or buried in the ground for several days, were used as feed for camels, cows and sheep, being more nutritious than barley $[4,28]$.

\section{Conclusion}

The nutritional value and beneficial health effects of the seven plant species discussed herein have been confirmed in literature. Pomegranates, grapes, date palm fruit, olives and figs are sources of antioxidants that can prevent diseases associated with oxidative stress. Due to their high polyphenol content, pomegranate fruit are used in human prostate cancer therapy and in antiatherogenic, antihypertensive, and anti-inflammatory treatments [34]. Polyphenols from grapes are thought to play a role in the prevention of cancer, type-2 diabetes mellitus, as well as neurodegenerative and cardiovascular diseases [35]. Date palm fruit, apart from their high nutritional value, have potential antioxidant, antibacterial, antifungal, and anti-proliferative properties [36]. Leaf and fruit extracts of the Ficus carica also contain a wide range of polyphenols, yet their antioxidant and anticancer effects are still poorly documented [37]. Everyday use of extra virgin olive oil promotes the absorption of fat-soluble vitamins found in food: A, $\mathrm{D}, \mathrm{E}$ and $\mathrm{K}$ [38]. It is also a rich source of monounsaturated fatty acids $[39,40]$. Whole-wheat grain contains starch, protein, B vitamins, dietary fiber, phytochemicals and minerals (iron, calcium, magnesium, sodium, zinc, copper and selenium) [41]. Wholegrain flour compared to white flour contains more essential amino acids [42]. Although cultivated in limited quantities, emmer wheat is still valued for baking bread, while durum wheat, excellent to produce pasta [43], is the second most widely cultivated wheat [44]. The seven species were essential components of the Ancient Israel diet, being at the same time remedies for many medical purposes.

\section{Disclosures/Conflict of interest}

The author declare that there is no conflict of interest.

\section{References}

1. Wasylikowa K (2001) The beginnings of growing plants: where, when, how and why. Botanical News 45(1-2): 7-31.

2. Achtemeier PJ (1999) The HarperCollins Bible Dictionary.

3. Dafni A, Böck B (2019) Medicinal plants of the Bible-revisited.JEthnobiol Ethnomed 15: 57

4. Hareuveni N (1996) Nature in Our Biblical Heritage.

5. Włodarczyk Z (2018) Biblical garden-A review, characteristics and definition based on twenty years of research. Folia Horticulturae 30(2): 229-248.

6. Włodarczyk Z, Kapczyńska A (2019) Biblical Gardens in Word Culture: Genesis and History. J Agric Environ Ethics 32: 835-854.

7. Arraf S (2006) From the field to the Table: Bread in Palestinian Culture and Tradition. in Bread Daily and Divine edited by Ben-Yossef N. The Israel Museum, Jerusalem.

8. Özkan H, Brandolini A, Schäfer-Pregl R, Salamini F (2002) AFLP Analysis of a Collection of Tetraploid Wheats Indicates the Origin of Emmer and Hard Wheat Domestication in Southeast Turkey. Mol Biol Evol 19(10): 1797-1801.

9. Lityńska-Zając M, Wasylikowa K (2005) Przewodnik do badań archeobotanicznych.

10. Nowiński M (1970) Dzieje upraw i roślin uprawnych.

11. Zohary M (1982) Plants of the Bible. A complete handbook to all the plants with 200 full-color plates taken in the natural habitat.

12. Hepper FN (1992) Pflanzenwelt der Bibel. Eine illustrierte Enzyklopadie.

13. Maillat J, Maillat S (1999) Les plantes dans la Bible.

14.Germer R (1985) Flora des pharaonischen Agypten. Deutsches Archaologisches Institut Abteilung Kairo.

15. Zohary D, Hopf M (2000) Domestication of plants in the old world: the origin and spread of cultivated plants in West Asia, Europe, and the Nile Valley.

16. Isserlin BSJ (1998) The Israelites.

17. Freeman JM (1996) Manners and Customs of the Bible

18. Borowski O (1987) Agriculture in iron age Israel.

19. Har-El M (2003) Landscape, Nature and Man in the Bible.

20. Goodnick-Westenholz J (1998) Sacred Bounty Sacred Land.

21. Stępniewska B (1987) Kompozycja zieleni cz. 1 Starożytność.

22. Feinberg Vamosh M (2006) Food at the Time of the Bible: From Adam's Apple to the Last Supper.

23. Rosso AM (2012) Beer and wine in antiquity: beneficial remedy or punishment imposed by the Gods? Acta Med Hist Adriat 10(2): 237-262.

24. Zohary M (1966) Flora Palaestina-part I.

25. Bauman H Die griechische Pflanzenwelt in Mythos, Kunst und Literatur. 26. Manniche L (1993) An Ancient Egyptian Herbal.

27. Krüssmann G (1978) Handbuch der laubgehölze, Band III.

28. Moldenke NH, Moldenke AL (1952) Plants of the Bible. 
29. Howell AB, D'Souza DH (2013) The Pomegranate: Effects on Bacteria and Viruses That Influence Human Health. Evidence-Based Complementary and Alternative Medicine 2013.

30. Mikołajczyk I (2004) Rzymska literatura agronomiczna.

31. El-Sohaimy SA, Hafez EE (2010) Biochemical and Nutritional Characterizations of Date Palm Fruits (Phoenix dactylifera L) 6(8):10601067.

32. Janick J, Paull RE (2008) The Encyclopedia of Fruit and Nuts.

33. Strzelecka H , Kowalski J (editor) (2000) Encyklopedia zielarstwa i ziołolecznictwa.

34. Zarfeshany A, Asgary S, Javanmard SH (2014) Potent health effects of pomegranate. Adv Biomed Res 3: 100.

35. Cosme F, Pinto T, Vilela A (2018) Phenolic Compounds and Antioxidant Activity in Grape Juices: A Chemical and Sensory View. Beverages 4: 22.

36. Al-Alawi RA, Al-Mashiqri JH, Al-Nadabi JSM, Al-Shihi BI, Baqi Y (2018) Date Palm Tree (Phoenix dactylifera L.): Natural Products and Therapeutic Options. Front Plant Sci 8: 845.

37. Purnamasari R, Winarni D, Permanasari AA, Agustina E, Hayaza S, et al. (2019) Anticancer Activity of Methanol Extract of Ficus carica Leave

\section{ISSN: 2574-1241}

DOI: $10.26717 /$ BJSTR.2020.25.004239

Zofia Włodarczyk. Biomed J Sci \& Tech Res

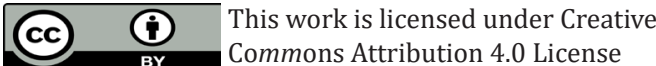

Submission Link: https://biomedres.us/submit-manuscript.php and Fruits Against Proliferation, Apoptosis, and Necrosis in Huh7it Cells. Cancer Inform 18: 1-7.

38. Albahrani AA, Greaves RF (2016) Fat-soluble vitamins: clinical indications and current challenges for chromatographic measurement. Clin Biochem Rev 37:27-47.

39. Kabaran S (2018) Olive Oil: Antioxidant Compounds and Their Potential Effects over Health. Intech Open.

40. Gorzynik-Debicka M, Przychodzen P, Cappello F, Kuban-Jankowska A Marino Gammazza A (2018) Potential Health Benefits of Olive Oil and Plant Polyphenols. Int J Mol Sci 19: e686.

41. Kumar P, Yadava RK, Gollen B, Kumar S, Verma RK, et al. (2011) Nutritional Contents and Medicinal Properties of Wheat: A Review. Life Sciences and Medicine Research 22: 1-10.

42. Shewry PR, Hey SJ (2015) The contribution of wheat to human diet and health. Food Energy Secur 4(3): 178-202.

43. Feinbrun-Dothan N (1986) Flora Palaestina, part 4 text, The Israel Akademy of Sciences and Humanities, Jerusalem.

44. Cooper R (2015) Re-discovering ancient wheat varieties as functional foods. J Tradit Complement Med 5(3): 138-143.

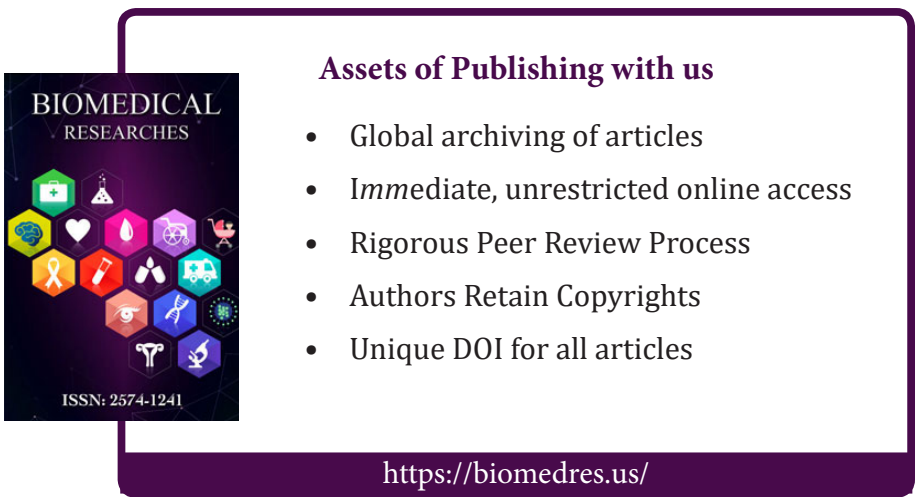

